\title{
A Comparison between English and Arabic Sound Systems Regarding Places of Articulation
}

\author{
Khawater Alshalaan \\ Al-Imam Muhammad Ibn Saud Islamic University, Riyadh, KSA \\ Email: kha.alshalan@gmail.com
}

How to cite this paper: Alshalaan, K. (2020) A Comparison between English and Arabic Sound Systems Regarding Places of Articulation. Open Access Library Journal, 7: e5679.

https://doi.org/10.4236/oalib.1105679

Received: August 8, 2019

Accepted: May 18, 2020

Published: May 21, 2020

Copyright $\odot 2020$ by author(s) and Open Access Library Inc.

This work is licensed under the Creative Commons Attribution International License (CC BY 4.0).

http://creativecommons.org/licenses/by/4.0/

\begin{abstract}
The English sound system differs from Arabic regarding places of articulation. Some of the English consonants do not exist in Arabic and vice versa. However, both languages share common palatal /j/. Arabic speakers find it difficult to pronounce / $/ \mathrm{s}$ sound and use /f/ instead. They also substitute /t/ and /d/ for /?/ and /e/. Arab speakers cannot pronounce the flap /s/ but stress the written /tt/. In English, / $t /$ is an aspirated alveolar but considered non-aspirated denti-alveolar in Arabic. As for $/ \mathrm{r} /$, it is always pronounced in Arabic but sometimes deleted in British English. Moreover, /?/ exists in Arabic as a consonant but alternative pronunciation in English.
\end{abstract}

\section{Subject Areas}

Linguistics

\section{Keywords}

English, Arabic, Sound Systems, Place of Articulation

\section{Introduction}

The linguistic system in both English and Arabic languages is entirely different. English is a descendant from a sub-family, which is Germanic of Indo-European language. Arabic is a descendant from Semitic family. Although English and Arabic differ in morphology, syntax and semantics, this essay will mainly focus on one aspect, which is phonetics. The English language contains twenty-six letters while Arabic has twenty-eight letters of the alphabet. Alphabets represent speech sounds. However, a crucial difference between English and Arabic is the sound system [1]. / $\mathbb{d} /$ is an emphatic consonant and a unique sound in Arabic. For this reason, Arabs named the Arabic language by the language of the Dad, which is the letter used for this unusual sound [1]. Using phonological catego- 
ries, such as place of articulation will often analyze speech segments [2] [3].

\section{English and Arabic Consonants}

There are many differences between English and Arabic consonants regarding their places of articulation. First, there are some Arabic consonants that do not

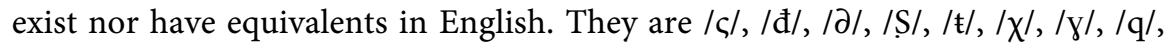
$/ \mathrm{h} /$, and $/ \mathrm{q} /$. However, the Arabic sound system lacks certain English consonants, such as $/ \mathrm{p} /, / \mathrm{t} / /, / \mathrm{d} 3 /, / \mathrm{J} /, / \mathrm{p} /$, and $/ \mathrm{v} /$. Despite this difference, English and Arabic share fourteen common consonants. They are $/ \mathrm{d} /, / \mathrm{b} /, / \mathrm{t} /, / \mathrm{j} /, / \mathrm{f} /, / \mathrm{z} /, / \mathrm{f} /, / \mathrm{h} /, / \mathrm{l} /$, $/ \mathrm{m} /, / \mathrm{n} /, / \mathrm{w} /, / \mathrm{r} / \mathrm{and} / \mathrm{y} /[4]$. When any of these consonants are spoken, friction occurs in the position of the tongue against the lips, teeth or roof of the mouth. Thus, friction is made depending on the nature of the produced sound.

\subsection{Labial}

Labial sounds consist of bilabial, labiovelar and labiodental sounds. Bilabial sounds are articulated between the upper and lower lips [4]. English bilabial consonants are $/ \mathrm{b} /, / \mathrm{p} /, / \mathrm{m} /$ and $/ \mathrm{w} /$, whereas Arabic has only $/ \mathrm{b} /$ and $/ \mathrm{m} /$ sounds. The aspirated $/ \mathrm{p} /$ does not occur in Arabic but it is for the sound $/ \mathrm{b} /$. Although, when using $/ \mathrm{b} /$ instead of $/ \mathrm{p} /$, the meaning of the words changes. For example /b $æ \mathrm{t} /$ is different from the word /p $æ \mathrm{t} /$ [5] All bilabial sounds can occur in three word positions; initial, medial and final. For example, $/ \mathrm{p} / \mathrm{in} / \mathrm{p}$ e $\mathrm{t} /$, /s p læ $\int /$ and /s 1 I: p/. /b/ in /b I t/, /k av b or / and /s t æ b/. Arabic/b/ can occur in /b æ $\mathrm{l}$ I $\mathrm{\gamma} /$ adult, / $\mathrm{k}$ ə $\mathrm{z} \mathrm{b}$ ə r a:/ cilantro and $/ \mathrm{t} \mathrm{u} \mathrm{r}$ a: b/ dust. $/ \mathrm{m} /$ sound is used in both English and Arabic; /m I: t/, animal /a n I m ə 1/ and /f a: $\mathrm{r} \mathrm{m} /$. Arabic $/ \mathrm{m} /$ in $/ \mathrm{m}$ ə d r I s ə h/ school, / $\mathrm{n}$ ə $\mathrm{m} \mathrm{l}$ æ h/ ant and / $\mathrm{k}$ ə r I: m/ generous. $/ \mathrm{w} / \mathrm{in} / \mathrm{w} \mathrm{eI} \mathrm{k} /, / \mathrm{k}$ av / and $/ \mathrm{l} \partial \mho /$. Arabic /w/ is considered one of the Labiovelar sounds that are produced when using the upper and lower lips with the soft palate [4]. For example, / $\mathrm{w}$ ə $\mathrm{r} \mathrm{d}$ ə h/ flower, / $/$ ə $\mathrm{z} /$ almonds and / $\mathrm{d}$ ə $\mathrm{l} \mathrm{u}$ :/ bucket.

\subsection{Labiodental}

Labiodental sounds are produced when the lower lip touches the upper teeth [4]. English contains two labio-dental sounds that are /f/ and /v/, whereas Arabic has /f/ but /v/ sound does not exist. Arab speakers can easily pronounce /f/ because it is one of Arabic sounds. However, they struggle in pronouncing /v/ sound. "Arabic doesn't have a contrastive /v/ sound" [6] to produce /v/, one should vibrate the sound between lips and teeth. [7] explains that Arabs have to pronounce $/ \mathrm{v} /$ as $/ \mathrm{f} /$. For example, saying the sentence "It is a fery nice fillage" reflects the fact that Arabic does not present the phoneme /v/. English /f/ and /v/ occur in all three positions; /f I: t/, /p I: $\mathrm{s}$ f ə l/ and /s k a: $\mathrm{r}$ f/; /v/ in /v æ n/, /g I v $\mathrm{e} \mathrm{n} /$ and /b r eI v/. Also, Arabic/f/ in /f I $\mathrm{ph}$ h/ class, /m u s æ f ə r/ traveller and / ə $\mathrm{r} \int$ ə f/ blanket.

\subsection{Dental}

Dental sounds are articulated with the tip or the blade of the tongue keeps in 
contact with the upper front teeth [4]. Dental sounds exist both in English and Arabic sound systems. However, in English, dental consonants include only /ð/ and $/ \theta /$, but in Arabic, there are dental and inter-dental consonants. Dentals involve $/ \mathrm{t} /, / \mathrm{t} /, / \mathrm{d} /, / \mathrm{d} /, / \mathrm{z} /, / \mathrm{n} /, / \mathrm{l} /, / \mathrm{s} /$ and the inter-dental consonants are $/ \theta /$ and $/ ð /$. Basically, there are two different ways to produce dental sounds. The first one is to use the tip of the tongue and put it at the back of the upper teeth without blocking the airflow by pressing hardly on them. English $/ \partial /$ and $/ \theta /$ occur initial, medial and final positions. /ð I s/, /b r a: $\partial$ ə r/ and /w I $/ / . / \theta /$ in thick / $\theta$ I $\mathrm{k} /, / \mathrm{p} \alpha \mathrm{I} \theta$ ə n/ and $/ \mathrm{b} \mathrm{r} \mathrm{I}: \theta /$. The second way is to use the blade of the tongue and makes it articulates with the bottom of the upper teeth. While the tip of the tongue protruding between the teeth and leaves enough space allowing the turbulent airstream to escape. This type is called inter-dental in Arabic, $/ \theta /$ and $/ \delta /$. for example, $/ \theta /$ in $/ \theta$ o b/, /m I $\theta$ ə l/ Same and /m u $\theta$ ə 1 æ $\theta /$ triangle. /ठ/ in / $/$ I: b/ wolf, /m ə ð y æ $/$ Radio and /r ə ðæ ð/ spray.

"Speakers of some dialects in Arabic may substitute /t/ and /d/ for $/ \Theta /$ and $/ ð /$ respectively, while speakers of other dialects may substitute /s/ and /z/". [6] According to [8], the dialect of Egyptian speakers is different from any other Arabic dialects (page 18-26). Even though $/ \theta /$ and $/ \partial /$ sounds are part of Arabic, the dental sounds are replaced with the sound /z/. In Egypt, people still struggle with pronouncing $/ \theta /$ and $/ \partial /$ correctly. The phoneme changed might change the meaning completely. For example, /s I $\mathrm{y} /$ instead of / $\theta \mathrm{I} \mathrm{y} / \mathrm{and} / \mathrm{z} \mathrm{eI} \mathrm{r} /$ instead of /ð eI r/.

\subsection{Alveolar}

Alveolar sounds are articulated with the tip or blade of the tongue against the alveolar ridge that is located behind the upper teeth [4]. English and Arabic alveolar sounds are /d/, /t/, /s/, /z/, /l/, /n/, /r/. Although, Arabic/t/, /d/ are called denti-alveolar. Alveolar sounds, $/ \mathrm{t} /$ and $/ \mathrm{k} /$, in both English and Arabic, are similar but not identical. The difference is in their place of articulation. [9] clarify that the English sound / $t$ / is an alveolar that becomes aspirated in the initial position of a word. For aspiration to happed, / $t /$ must be followed by a strong vowel, such as tea /t I:/, whereas Arabic, /t/ is denti-alveolar. In the same word position, /t I n/, initial /t/ is non-aspirated. Moreover, Alveolar sounds occur in all three positions; /t/ in /t u/, /b u t ə n/ and / $\mathrm{k}$ a n t/. Arabic/t/ in /t ə $\mathrm{m}$ e r/ dates,

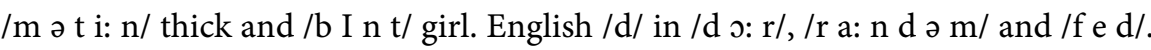
Arabic /d/ in /d ə m/ bood, /t ə q a dd $v \mathrm{~m} /$ advance and /b æ $\mathrm{r}$ e d/ cold. English /s/ in /s avə r/, /b æ s k I t/ and final /t e k s t s/. Arabic/s/ in /s ə r I: r/ bed, /r ə s $\mathrm{I} \mathrm{m} / \mathrm{draw}$ and $/ \mathrm{\int} \partial \mathrm{m} \mathrm{s} / \mathrm{sun}$.

Flap /s/ is a popular sound in English. "It is produced like /d/, except the tongue touches or flaps against the alveolar ridge only very briefly" [3]. Unlike English, this sound is not common in native Arabic language. Thus, Arab speakers are cannot pronounce the flap easily. They might pronounce it as $/ \mathrm{t} /$ sound. For example, Seattle has a flap in the middle of the word. Arab speakers stress the written /tt/ and try to pronounce the sound / $t$ / heavily. 
More alveolar sounds appear in words like /z u:/, /f $\mathrm{r}$ əひ z I n/ and /s n I: z/.

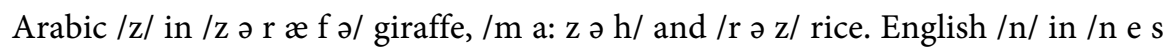
$\mathrm{t} /$, /b e $\mathrm{nt}$ / and /f u n/. Arabic /n/ in /n u: r/ light, /b I n t/ girl and /m ə kæ n/ place. English /l/ in /l eI/, /b læ s t/ and /t avə 1/. Arabic /l/ in /l əu n/ colour, /m ə 1 æ b I s/ clothes and /r ə $\mathrm{m}$ I l/ Sand. English /r/ in /r eI t/, /b r eI t/ and /k a: r/. Arabic /r/ in / $\mathrm{r}$ ə $\mathrm{m} \mathrm{u}$ : $\mathrm{z} /$ symbols, / $\mathrm{k} \mathrm{r} \mathrm{t/card} \mathrm{and} \mathrm{/m} \mathrm{ə} \mathrm{k} \mathrm{s} \mathrm{u:} \mathrm{r} /$ broken.

In many accents and dialects, $/ \mathrm{r} /$ sound is pronounced differently [10]. In RP, $/ \mathrm{r} /$ is a post-alveolar sound and a frictionless continuant. The tip of the tongue comes close to the alveolar ridge but not touching. It makes a quick frictionless glide sound [11]. Both in English and Arabic, /r/ could be a rolled sound that is pronounced by tapping the tongue quickly at the alveolar ridge [12]. Although, $/ \mathrm{r} /$ is always strongly pronounced in Arabic and can never be deleted in any situation. Unlike British English, where / $\mathrm{r} /$ is deleted if it is followed by a consonant. In addition, "The English / $r$ / may be pronounced as a trill". [6] Though, Arab speakers might struggle with dark palatal liquid /r/. There are two ways to pronounce $/ \mathrm{r} /$ in English; voiced palatal liquid, such as $/ \mathrm{r} /$ in $/ \mathrm{p} \mathrm{I}$ : $\mathrm{t}$ a $\mathrm{r} /$ and voiced alveolar liquid, like $/ \mathrm{r}$ eI n/.

\subsection{Palato-Alveolar}

Palato-alveolar sounds are articulated with the blade of the tongue behind the alveolar ridge and the body of the tongue raised toward the hard palate [4]. English palato-alveolar sounds are $/ \mathrm{J} /, / 3 /, / \mathrm{t} / \mathrm{l} / \mathrm{d} 3 /$, while Arabic has only one palato-alveolar sound, which is $/ \int /$. English $/ \delta /$ in $/ \int \mathrm{u}: \mathrm{t} /$, /f I $\int$ ə $\mathrm{r} /$ and $/ \mathrm{k} \mathrm{r} æ \int /$. Arabic / $/$ / in $/ \int$ ə $\mathrm{m}$ s/ sun, / $\mathrm{w}$ ə $\int \mathrm{I} \mathrm{m} /$ tattoo and / $\mathrm{r}$ a: $\int /$ bed. However, there is no $/ \mathrm{t} / /$ sound in Arabic that is pronounced in the palatal place of articulation. Because of the fact that $\mathrm{Ch}$ is sometimes pronounced as $/ \mathrm{k} /$, such as Chris, Arab speakers tend to overgeneralize the rule and pronounce words that start with $/ \mathrm{t} / \mathrm{f}$ with /k/ sound. In Chair, Ch it is most likely pronounced as $/ \mathrm{k} \mathrm{eI} \mathrm{r/.} \mathrm{/t} /$ occurs

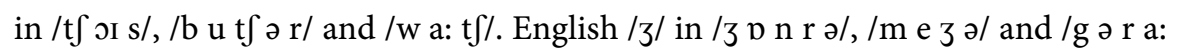
3/. English /dz/ in /dz $æ \mathrm{k} \mathrm{I} \mathrm{t/,} \mathrm{/p} \mathrm{b} \mathrm{d} 3$ e k t/ and /a k n p l I d $3 /$.

\subsection{Velarised Alveolar}

Velarised alveolar consonants and Velarised denti-alveolar sounds do not exist in English. Velarised alveolar sounds are produced by using the blade of the tongue and makes reach the alveolar ridge closely. This Arabic sound is / $\mathbf{S} /$ as in /S u: S/ chicks, /b a S a r/ sight and /r a q s/ Dance. Velarised denti-alveolar sounds are difficult to pronounce because they have a very different manner. Non-native Arabic speakers can never pronounce these sounds clearly as natives.

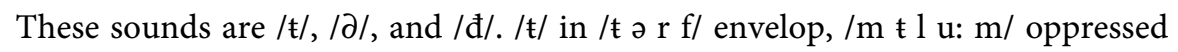
and /f $ә \mathrm{t} /$ rude. $/ \partial / \mathrm{in} / \partial \mathrm{m}$ a: $\partial \partial \mathrm{m} /$ tomato, $/ \mathrm{m}$ ə $\partial$ ə $\mathrm{r} /$ rain and $/ \mathrm{r}$ ə b a: $\partial /$ tie. /đ/ in /đ ə b/ lizard, /m a: đ I:/ past and /n ə b đ/ pulse.

\subsection{Palatal}

Palatal sounds are produced when the tongue body articulates with the hard pa- 
late. English and Arabic contain one palatal sound, which is $/ \mathrm{j} /$. English $/ \mathrm{j} / \mathrm{in} / \mathrm{j}$ u: r/, /t u: j s d eI/ and /m eI/. Arabic/j/ in /j ə m I: n/ right, /h ə y æ h/ Life and /k u r s I:/ chair. As for the sounds /dz/ and /g/, Arabic does not contain them as consonants [11] However, /d/ and / $/$ / are considered allophones to the Arabic consonant Jeem. They are pronounced separately but never pronounced together as $/ \mathrm{d} 3 /$. As a result, Arabic speakers might mispronounce the $/ \mathrm{d}_{3} /$ sound as /g/, such as pronouncing "just” as /gnst/ [13].

\subsection{Velar}

Velar sounds are produced when the body of the tongue reaches the velum or soft palate [4]. English velar sounds are $/ \mathrm{k} /, / \mathrm{g} /$, and $/ \mathrm{n} /$. $/ \mathrm{k} /$ as in $/ \mathrm{k} \mathrm{eI} \mathrm{k/,} \mathrm{/b} \mathrm{ə} \mathrm{k} \mathrm{I}$ $\mathrm{t} /$ and $/ \mathrm{b} æ \mathrm{k} /$. /g/ in /g eI m/, /b I g I n/ and /b I g/. /y/ sound does not occur initially; only middle and final positions. For instance, /s I y/ and /s I y ə r/. Even though, $/ \mathrm{n} /$ does not exist as an independent consonant in Arabic, Arab speakers pronounce $/ \mathrm{n} /$ only when it occurs before the $/ \mathrm{k} /$ sound, such as $/ \mathrm{d} \mathrm{r}$ i $\mathrm{n} \mathrm{k} /$ and $/ \theta æ \mathrm{n} /$. However, there is struggle in pronouncing $/ \mathrm{n} /$ alone in its final position; the "ing" syllable. It is often immediately related to the /g/ sound, like in: /w er $\mathrm{t}$ I $\mathrm{g}$ g/, / $\mathrm{h} æ \mathrm{p}$ n I $\mathrm{g}$ g/, and /s $\Lambda$ m $\theta$ I $\mathrm{g}$ g/ [5]. Additionally, Arabic velars are /k/ and /q/. /k/ in /k I $æ$ b/ book, / $\mathrm{r} \mathrm{u} \mathrm{k} ə \mathrm{n} /$ corner and /b $\Lambda \mathrm{nk}$ / bank. /q/ in /q ə $\mathrm{z}$ ə h/, /b ə q ə r ə h/ cow and /s æ q/ leg.

\subsection{Uvular}

Uvular sounds do not occur in English. They are pronounced by using back of the tongue and uvula, such as $/ \mathrm{\gamma} /$ and $/ \mathrm{x} /$. For instance, $/ \mathrm{y}$ ə b i/ idiot, $/ \mathrm{m} \Lambda \mathrm{y} \mathrm{n}$ a: $\partial \mathrm{I}$ : s/ magnets and /S $\Lambda \mathrm{m} \mathrm{\gamma} /$ glue. $/ \mathrm{x} /$ as in $/ \mathrm{x}$ a: $\mathrm{x} /$ peach, $/ \mathrm{n} \Lambda \mathrm{x} \mathrm{l}$ ə h/palm tree and $/ \mathrm{k}$ u: $\mathrm{x} /$ cottage. $/ \mathrm{x} /$ and $/ \mathrm{y} /$ sound might be considered as velar, post-velar or uvular pronunciations.

\subsection{Pharyngeal}

Pharyngeal sounds are pronounced by using the back of the tongue and pharynx. Usually, sounds systems of all languages from all around the world are produced from the larynx to the lips. However, the Arabic consonantal system is unique because it differs from any other language system. It consists of a sound class that is pronounced in the area between the larynx and the upper pharynx. Arabic has two pharyngeal consonants / $\mathrm{h} /$ and / / / that both do not exist in Eng-

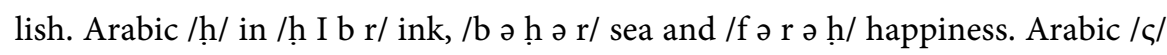

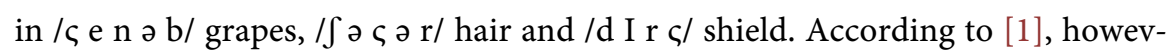
$\mathrm{er}, / \mathrm{h} /$ and $/ \varsigma /$ are categorized as one of the epiglottal sounds in many varieties.

\subsection{Glottal}

Glottal sounds are pronounced in the opening area between the vocal folds, called glottis. Glottal consonants, / / / and /h/ exist in both English and Arabic. Although, / / in English is an alternative pronunciation. For example, /?/ may 
appear in the word batman /b ə / $7 \mathrm{~m} æ \mathrm{n} /$. Arabic / $/$ /as in / $/ \mathrm{m} \mathrm{I}: \mathrm{r}$ ə h/ princess, /k ə ? I: b/ depressed and /b ə r I: ?/ innocent. /h/ is categorized as a glottal consonant because the opening of the vocal cords becomes narrow when producing it. The airstream passes the vocal cords and creates turbulence [4]. In Arabic, /h/ could occur in all three positions; initial, medial and final positions. In English though, /h/ never occurs in final positions of words. English /h/ in /hæ $\mathrm{p} \mathrm{I:/} \mathrm{and}$ /b I h a: f/. Arabic/h/ in /h æ t I f/ telephone, /k ə h f/ cave and /d ə $1 æ 1$ ə h/ indication.

\section{Conclusion}

The English sound system differs from Arabic regarding places of articulation. Some of the English consonants do not exist in Arabic and vice versa. However, both languages share common palatal $/ \mathrm{j} /$. Arabic speakers find it difficult to pronounce $/ \mathrm{v} /$ sound and use /f/ instead. They also substitute /t/ and /d/ for $/ \theta /$ and $/ \delta /$. Arab speakers cannot pronounce the flap /s/ but stress the written /tt/. In English, / $t /$ is an aspirated alveolar but considered non-aspirated denti-alveolar in Arabic. As for $/ r /$, it is always pronounced in Arabic but sometimes deleted in British English. Moreover, / $/$ / exists in Arabic as a consonant but alternative pronunciation in English.

\section{Conflicts of Interest}

The author declares no conflicts of interest regarding the publication of this paper.

\section{References}

[1] Bite, V. (2013) Arabic and English Phonetics: A Comparative Study. The Criterion: An International Journal in English, 4, 1-13. http://www.the-criterion.com/V4/n4/Javed.pdf

[2] Chomsky, N. and Halle, M. (1968) The Sound Pattern of English. Harper Row, New York.

[3] Jakobson, R., Fant, C.G.M. and Halle, M. (1951) Preliminaries to Speech Analysis: The Distinctive Features and Their Correlates. MIT Press, Cambridge.

[4] Sabir, I. and Alsaeed, N. (2014) A Brief Description of Consonants in Modern Standard Arabic. Linguistics and Literature Studies, 2, 185-189.

[5] Celce-Murcia, M., Brinton, D. and Goodwin, J. (2010) Teaching Pronunciation: A Course Book and Reference Guide. Cambridge University Press, New York.

[6] Avery, P. and Ehrlich, S. (1992) Teaching American English Pronunciation. Oxford University Press, New York.

[7] Zarka, A.M.E.S. (2013) The Pronunciation Errors of L1 Arabic Learners of L2 English: The Role of Modern Standard Arabic and Vernacular Dialects Transfer. The British University, Dubai, 1-75.

[8] Wise, H. (1975) A Transformational Grammar of Spoken Egyptian Arabic. Basil Blackwell, London.

[9] Hago, O. and Khan, W. (2015) The Pronunciation Problems Faced by Saudi EFL 
Learners at Secondary Schools. Education and Linguistics Research, 1, 85-99. https://doi.org/10.5296/elr.v1i2.7783 $\square$

[10] Roach, P. (2009) English Phonetics and Phonology: A Practical Course. 4th Edition, Cambridge University Press, Cambridge.

[11] Rogerson-Revell, P. (2011) English Phonology and Pronunciation Teaching. Continuum Press, London.

[12] O’Connor, J.D. (1980) Better English Pronunciation. Cambridge University Press, Cambridge.

[13] Chouchane, A. (2016) Prononciation Difficulties for Arab Learners of English. Global English-Oriented Research. Sohar University, Oman. 